\title{
EFFECTS OF VERMICOMPOST, FERTILIZER AND MULCH ON PLANT GROWTH, NODULATION AND POD YIELD OF FRENCH BEAN (PHASEOLUS VULGARIS L.)
}

\author{
B.K. SINGH ${ }^{1}$, K.A. PATHAK ${ }^{1}$, A.K. VERMA ${ }^{2}$, V.K. VERMA ${ }^{1}$, B.C. DEKA ${ }^{2}$ \\ ${ }^{1}$ ICAR Research Complex for NEH Region, \\ Mizoram Centre, Kolasib-796081, Mizoram, India \\ ${ }^{2}$ ICAR Research Complex for NEH Region, \\ Umroi Road, Barapani-793108, Meghalaya, India
}

Received: February 13, 2010; Accepted: June 13, 2011

\begin{abstract}
Summary
Integration of vermicompost and organic mulch as elements of vegetable production system sustain soil fertility and crop productivity. A field experiment was conducted with the objective to investigate the effects of vermicompost, NPK fertilizer and organic mulch on crop growth, nodulation and pod yield of French bean (Phaseolus vulgaris L.) with an ultimate aim of optimizing water and nutrient requirement in mild-tropical climate during dry season. The shoot growth traits, namely shoot length, number of primary branches, shoot fresh weight and shoot dry weight were increased by $28-63 \%$ through application of $\mathrm{N} \mathrm{P}_{2} \mathrm{O}_{5} \mathrm{~K}_{2} \mathrm{O} 8: 13: 10 \mathrm{~kg} \cdot \mathrm{ha}^{-1}+$ vermicompost $3.75 \mathrm{t} \cdot \mathrm{ha}^{-1}$ and by $5-50 \%$ in organic mulching treatments. Application of vermicompost reduced nodule fresh weight and nodule dry weight by 44.9 and $44.5 \%$, respectively. Likewise, corresponding nodule number, nodule fresh weight and nodule dry weight were reduced by $8.6,11.1$ and $14.1 \%$ with organic mulching. Poor nodulations might be due to reduced oxygenation of the soils under vermicompost and organic mulch which is ultimately impeding the nitrogenase activity and biological nitrogen fixation. Mulching of French bean with dried grasses and crop residues are also led to higher single pod weight, pod length, pod weight/plant and pod yield by $10.9,12.8,20.1$ and $20.2 \%$, respectively. Present study shows that application of $\mathrm{N}_{2} \mathrm{O}_{5} \quad \mathrm{~K}_{2} \mathrm{O}$ fertilizer 8-15:13-25:10-20 kg ha ${ }^{-1}$, vermicompost 2.50-3.75 $\mathrm{t} \cdot \mathrm{ha}^{-1}, 4 \mathrm{~cm}$ thick mulch of dried crop residues and 50\% irrigation is the most suitable and sustainable strategy to improve plant growth, pod formation and pod yield of French bean, and soil health of mild-tropical climate during dry season.
\end{abstract}

key words: French bean (Phaseolus vulgaris), mulching, vermicompost, nodulation, pod yield, split plot design (SPD) 


\section{INTRODUCTION}

French bean (Phaseolus vulgaris L.) is one of the most widely cultivated vegetable crops for their tender pods and fresh seeds in Mizoram as well as North East states of India. It is grown during the winter, spring and rainy seasons. The pod yield during winter period is limited by acute soil moisture stress caused by high rate of evapo-transpiration, almost no rain from November-March and low water holding capacity of the sloppy land; despite optimum temperature and appropriate length of day for crop growth, flowering and pod formation. Higher frequency of irrigation could be used to alleviate soil moisture stress. However, the acute shortage of irrigation water in this region necessitates its economy. One way of achieving this is by mulching with cropforest residues. Integration of vermicompost along with NPK fertilizers is another way to sustain the productivity by using the local organic cropplant-forest wastes. Humans, livestock and crops-plants-forest produce approximately 600 to 700 million metric tons of agricultural wastes (including 272 million metric tons of crop-plants-forest residues) in India every year, but most remains unutilized (Suthar 2009). In most parts of Mizoram and the North East Hill Regions of India, forest and crop-plant residues are available in abundant. These organic residues could be converted into nutrient rich vermicompost and used as mulch to sustain the vegetable productivity.

Mulch improves the soil environment; stimulates microbial activity; enhances oxygen availability to roots; moderates soil temperature; increases soil porosity and water infiltration; increases nutrient availability; reduces evaporation, fertilizer leaching and soil compaction; controls weeds, runoff and soil erosion; and increases plant growth, yield and quality (Bhatt \& Khera 2006, Anikwe et al. 2007, Sarkar \& Singh 2007, Sarkar et al. 2007, Glab \& Kulig 2008, Liasu et al. 2008, Ekinci \& Dursun 2009, Rashidi et al. 2009, Arora et al. 2011, Vanlalhluana \& Sahoo 2011). Vermicompost is an eco-friendly, cost effective and ecologically sound bio-fertilizer. Use of vermicompost is effective for improving soil aggregation, structure, aeration and fertility; contains most of the nutrients in plant-available form such as nitrates, phosphates, exchangeable calcium and soluble potassium; increases beneficial microbial population diversity and activity; improves soil moisture-holding capacity; contains vitamins, enzymes and hormones; and accelerates the population and activity of earthworms (Aggelides \& Londra 1999, Mascolo et al. 1999, Albiach et al. 2000, Marinari et al. 2000, Sailajakumari \& Ushakumari 2002, Arancon et al. 2006, Prabha et al. 2007, Azarmi et al. 2008). Vermicompost has a significant positive influence on seed germination and seedling vigor, plant growth, flowering, fruiting, tuberization, root development, colour, shelf-life and quality of vegetables (Atiyeh et al. 2001, Suthar et al. 2005, Arguello et al. 2006, Alam et al. 2007, Ansari 2008, Gupta et al. 2008, Peyvast et al. 2008, Premsekhar \& Rajashree 2009, Suthar 2009, Chanda et al. 2011).

Poor soil respiration and complete destruction of natural decom- 
poser communities from agro-ecosystems threatens sustainability as well as food security. Similarly, escalation in cost of chemical fertilizers (particularly $\mathrm{N}, \mathrm{P}$ and $\mathrm{K}$ ) and irrigation water, reduced water table, higher cost of fertilizer transportation in hilly regions of North East India, and ecological concerns toward natural resources management and human health have increased interest of use of integrated approaches for sustainable production. Keeping these in view, the study was undertaken to ascertain effects of vermicompost, fertilizer and mulching on crop growth, nodulation and green pod yield of French bean during dry conditions.

\section{MATERIALS AND METHODS}

The experiment was carried out at the Research Farm, ICAR Research complex for NEH Region, Mizoram Centre, Kolasib, Mizoram (24\% $12^{\prime} \mathrm{N}$, $92^{\circ} 40^{\prime} \mathrm{E}$ and $650 \mathrm{~m}$ above sea level) during 2009-2010. The soil type is an Alfisol and acidic in soil reaction $(\mathrm{pH}$ 5.8). The terraced field was tilled and divided into plots $(4 \times 2.5 \mathrm{~m})$. A 60 $\mathrm{cm}$ wide space was left between plots. The experiment was laid-out in split plot design (SPD) with three replications. The treatments comprised five nutrition regimes $\left(\mathrm{N} 1: \mathrm{N}_{2} \mathrm{O}_{5} \mathrm{~K}_{2} \mathrm{O}\right.$ 30:50:40 kg ha ${ }^{-1}, \quad \mathrm{~N} 2: \mathrm{N}_{2} \mathrm{P}_{2} \mathrm{O}_{5} \quad \mathrm{~K}_{2} \mathrm{O}$ 22.5:37.5:30 kg $\cdot \mathrm{ha}^{-1}+$ vermicompost 1.25 t $\cdot$ ha $^{-1}, \mathrm{~N} 3: \mathrm{N} \mathrm{P}_{2} \mathrm{O}_{5} \mathrm{~K}_{2} \mathrm{O}$ 15:25:20 $\mathrm{kg} \cdot \mathrm{ha}^{-1}+$ vermicompost $2.5 \mathrm{t} \cdot \mathrm{ha}^{-1}, \mathrm{~N} 4$ : $\begin{array}{llll}\mathrm{N}_{2} \mathrm{P}_{2} & \mathrm{~K}_{2} \mathrm{O} & 7.5: 12.5: 10 \mathrm{~kg} \cdot \mathrm{ha}^{-1}+\end{array}$ vermicompost $3.75 \mathrm{t} \cdot \mathrm{ha}^{-1}$ and $\mathrm{N} 5$ : vermicompost $5 \mathrm{t} \cdot \mathrm{ha}^{-1}$ ) in the mainplots, and two mulching treatments such as without-mulch and organic mulch in the sub-plots. The N1 treat- ment contains $\mathrm{N}_{2} \mathrm{O}_{5} \mathrm{~K}_{2} \mathrm{O}$ 30:50:40 $\mathrm{kg} \cdot \mathrm{ha}^{-1}$, i.e. rate of nutrients. Vermicompost was prepared from crop residues and 15 day-old cow-dung in 1:4 ratios using red crawler earthworm (Eisenia foetida) under shednet. The uniform dose of FYM 3.0 $\mathrm{t} \cdot \mathrm{ha}^{-1}$ and lime $2 \mathrm{t} \cdot \mathrm{ha}^{-1}$ was applied to the each plots at last tilling. The fertilizers $(\mathrm{N}, \mathrm{P}$ and $\mathrm{K}$ ) were supplied by urea, single superphosphate (SSP) and muriate of potash (MOP), respectively and mixed thoroughly during plot preparation. Locally available dried grasses and crop residues were used as mulch (4 cm thick) and mulching was done at 15 days after sowing. The seeds of French bean cv. Arka Komal were sown in lines spaced at $40 \mathrm{~cm}$ during second week of November 2009. Plants were thinned, to maintain the plant to plant spacing of $10 \mathrm{~cm}$, at 20 days after sowing. All the treatments received only 50\% irrigation. During the crop period (November-25 March), a total rainfall of $2 \mathrm{~mm}$ was received.

All observations were recorded on 15 randomly chosen plants, other than root related parameters, in each treatment and replication. Data on days to $50 \%$ flowering were, however, taken on the whole plot basis. Shoot length, primary branches, trifoliate number and related growth parameters were measured at full-bloom stage. To estimate the leaf area, leaf weight and specific leaf weight, the leaves of $3^{\text {rd }}, 4^{\text {th }}$ and $5^{\text {th }}$ trifoliate from plants were sampled at full-bloom stage in each replication. Root weight, root length, nodule number and nodule weight were recorded by uprooting 10 plants form each replication at full-bloom stage. The pods were 
picked in the green maturity stage, counted, measured and weighed to determine total yield. Plot means were computed, and were subjected to analysis of variance (ANOVA) and Duncan's multiple range test (DMRT) using IRRISTAT software (Version 3/93, Biometrics Unit, International Rice Research Institute, Manila, Philippines) to identify homogeneity of data between treatment combinations.

\section{RESULTS AND DISCUSSION}

The partitioning of estimates of analysis of variation (ANOVA) into main-plot (nutrition), sub-plot (mulching), and interaction between mainplot and sub-plot revealed that mean squares due to nutrition were significant for all the traits, apart from days to $50 \%$ flowering, root length, root dry weight and nodule number, which are indicating that various levels of $\mathrm{N}$ $\mathrm{P}_{2} \mathrm{O}_{5} \quad \mathrm{~K}_{2} \mathrm{O}$ fertilizers and vermicompost affecting the plant growth and productivity (Table 1). All the traits, other than number of trifoliate and leaf, and pod number per plant, were significantly affected by organic mulch showing the importance of mulching in growth and yield of bean.

Effect of vermicompost, fertilizer and mulching on plant growth and nodulation of French bean

The various combinations of nutrition significantly affect the shoot length, number of primary branches, shoot fresh weight, shoot dry weight, root fresh weight, nodule fresh weight and nodule dry weight; nevertheless days to $50 \%$ flowering, root length, root dry weight and number of nodule per plant were not affected by nutrition (Table 2). Moreover all the parame- ters of growth and nodulation were significantly affected by mulching with dried grasses and crop residues.

Days to $50 \%$ flowering was extended by three days by application of mulch. This is only due to higher vegetative growth delayed the reproductive phase. The traits related to aboveground plant growth, namely shoot length, number of primary branches, shoot fresh weight and shoot dry weight were measured maximum, i.e. increased by $28-63 \%$ in $\mathrm{N} 4$ treatment (25\% rate of nutrients + vermicompost $3.75 \mathrm{t} \cdot \mathrm{ha}^{-1}$ ) and $5-50 \%$ higher in mulching plots. The proper balance of organic and inorganic nutrients and uniform moisture and temperature regimes by organic mulching provided a better conducive rhizospheric condition and in turn helped the plants to boost their growth remarkably. These results show that increase in plant growth could probably be due to improvement in the physio-chemical properties of soil, increase in enzymatic activity, increase in microbial population and activity and easy availability of macro- and micronutrients by application of vermicompost and organic mulching (Mascolo et al. 1999, Albiach et al. 2000, Arancon et al. 2006, Prabha et al. 2007, Azarmi et al. 2008, Ekinci \& Dursun 2009).

Root length, root fresh weight and root dry weight were measured significantly higher $(32.1,29.0$ and $17.5 \%$, respectively) in mulching treatment. The root growth intensity was comparatively lower for dry weight than root length and root fresh weight. It is interesting to note that nodulation parameters, namely nodule number, nodule fresh weight and nod- 
ule dry weight were reduced drastically by application of vermicompost and organic mulching, apart from nodule number by vermicompost. Vermicompost reduced nodule fresh weight and nodule dry weight by 44.9 and $44.5 \%$, respectively. Similarly, corresponding nodule number, nodule fresh weight and nodule dry weight were reduced by $8.6,11.1$ and $14.1 \%$ with organic mulching. Decrease in nodulation upon application of vermicompost could have been caused by overtaking of the rhizosphere by fungi over bacteria which might now have to compete for the carbon source with the fungi for multiply to achieve a population count that is optimal for host infection. We believe that in our case the fungi might be aiding the growth more than the rhizobacteria that is nutritional advantage of fungi overtakes nitrogen fixation advantage of bacteria. As for negative effect of mulching on nodulation, might be due to reduced oxygenation of the soils that are already acidic and not very congenial for bacterial reproduction and survival.

Effect of vermicompost, fertilizer and mulching on leaf growth of French bean

The parameters related to leaf growth were significantly influenced by nutrition dosages and mulching, except number of trifoliate and leaves by organic mulching (Table 3). The N4 treatment $(25 \%$ rate of nutrients + vermicompost $3.75 \mathrm{t} \cdot \mathrm{ha}^{-1}$ ) was observed maximum trifoliate, leaves, leaf area and leaf weight, in general, which was at par with $\mathrm{N} 3$ treatment (50\% rate of nutrients + vermicompost $\left.2.50 \mathrm{t} \cdot \mathrm{ha}^{-1}\right)$. This might be due to beneficial effects of vermicompost. Leaf area and leaf weight was increased by $11-26 \%$ by organic mulching. Hence, the results emphasize the integration of organic sources of nutrition and mulching will provide maximum area for $\mathrm{CO}_{2}$ fixation and in turn helped the plants to boost their growth. Singh et al. (2010) and Adetunji (1990) have reported similar findings in tomato and lettuce, correspondingly. Specific leaf weight showed decreasing pattern by increasing the amounts of vermicompost and application of organic mulch. The finding clearly shows that vermicompost and organic mulching play an important role towards partitioning of photo-assimilates from vegetative source to reproductive sink (leaf to green pod) which will ultimately lead to development of yield attributes. The finding is close conformity with those of Singh et al. (2010) in tomato. more with $\mathrm{N} 3$ followed by $\mathrm{N} 2$ and N4. The increased yield potential of vegetables through application of vermicompost and mulching has also confirmed by Singh et al. (2010), Suthar (2009) and Liasu et al. (2008). 


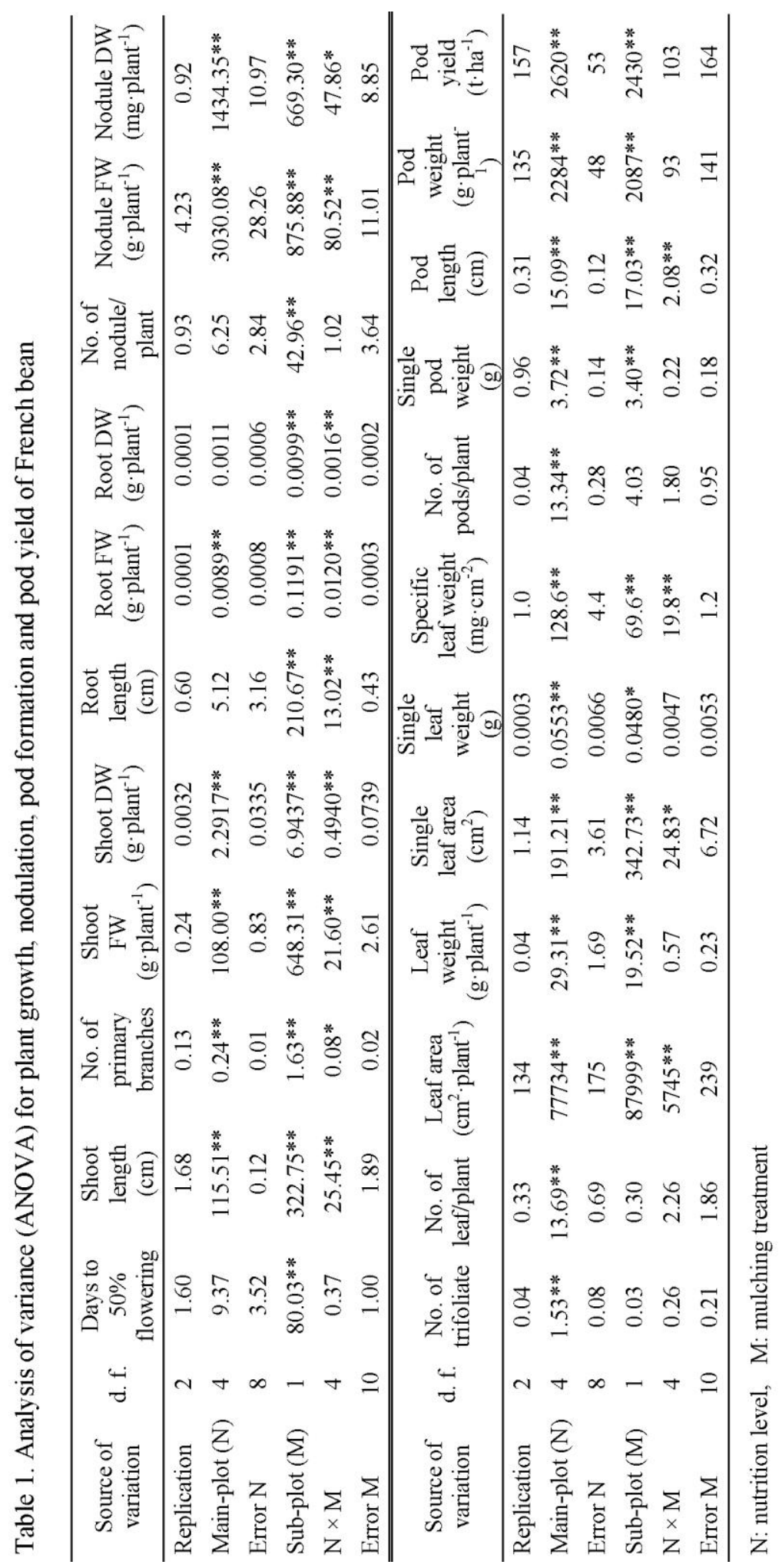




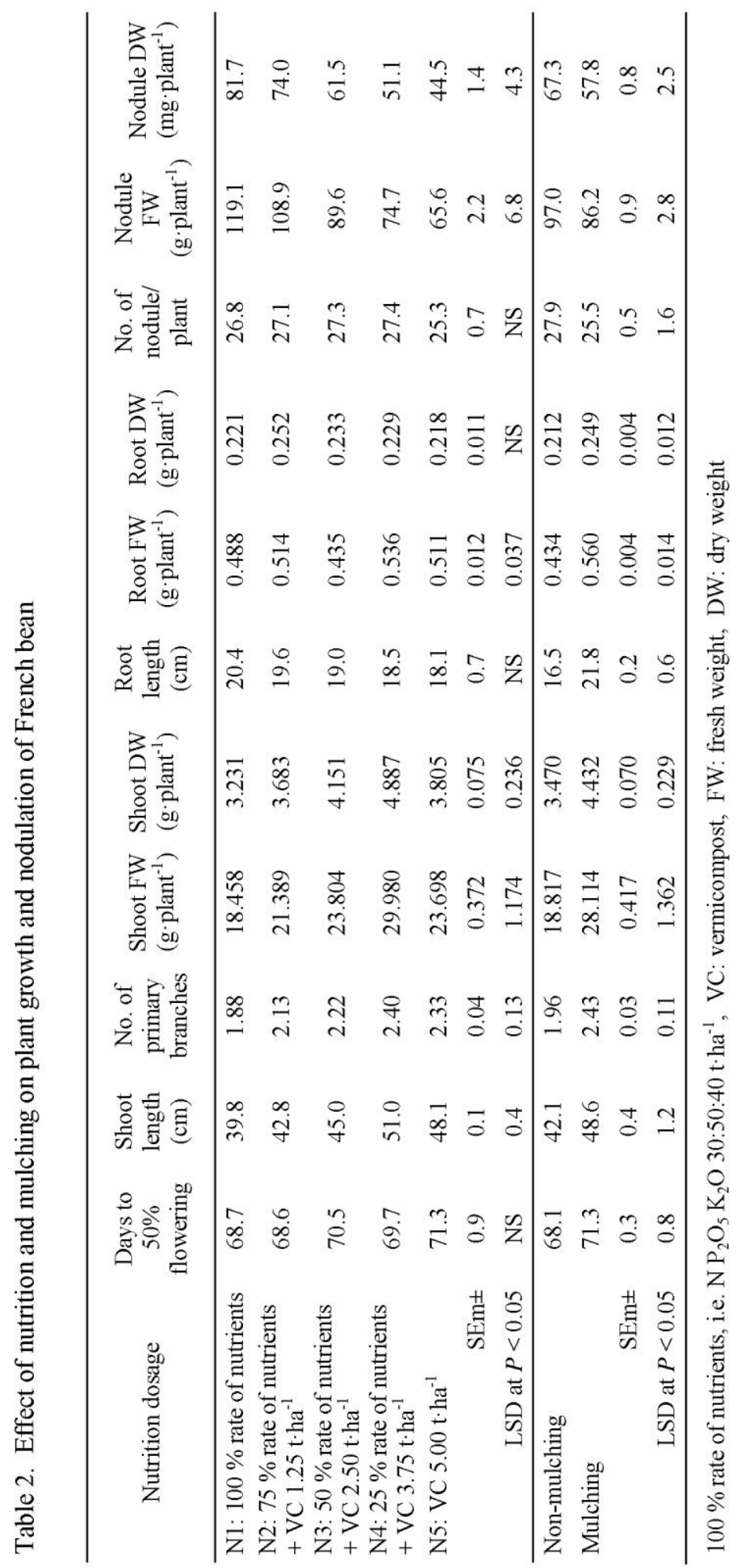




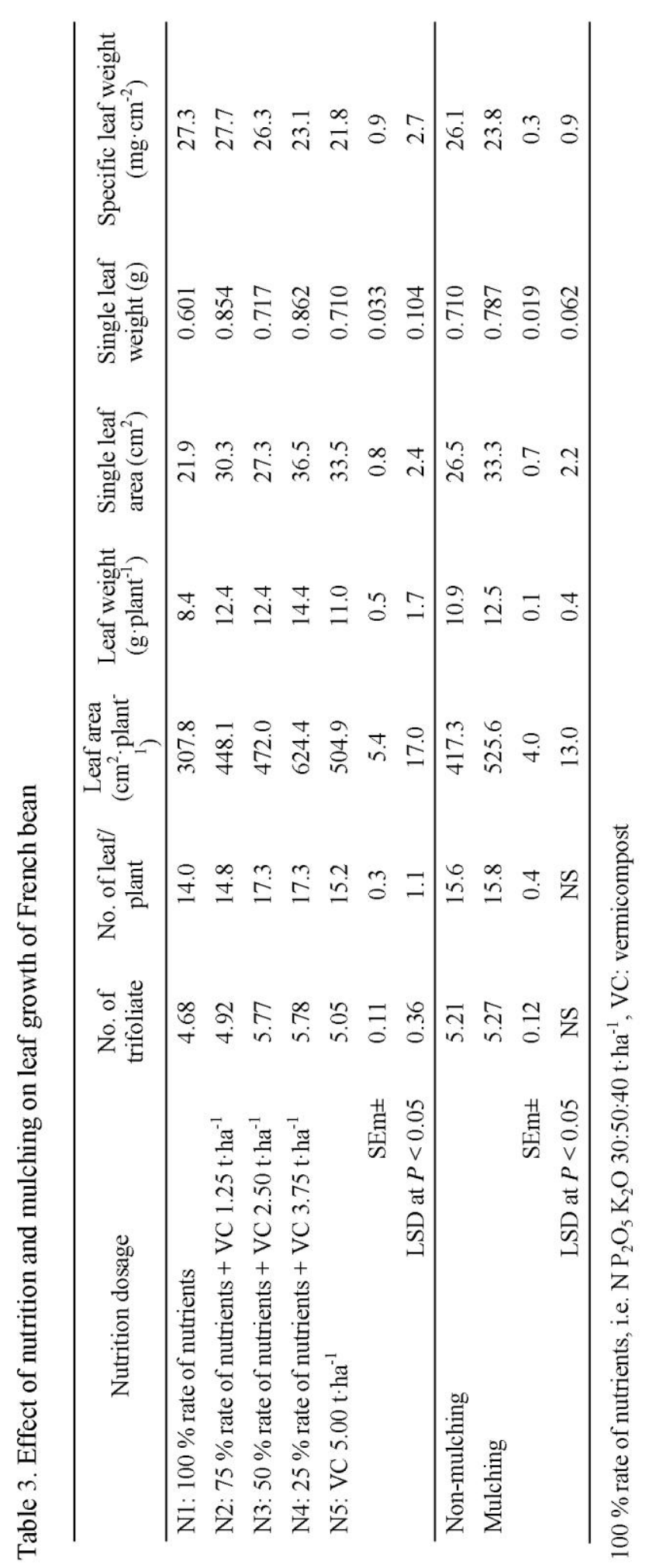




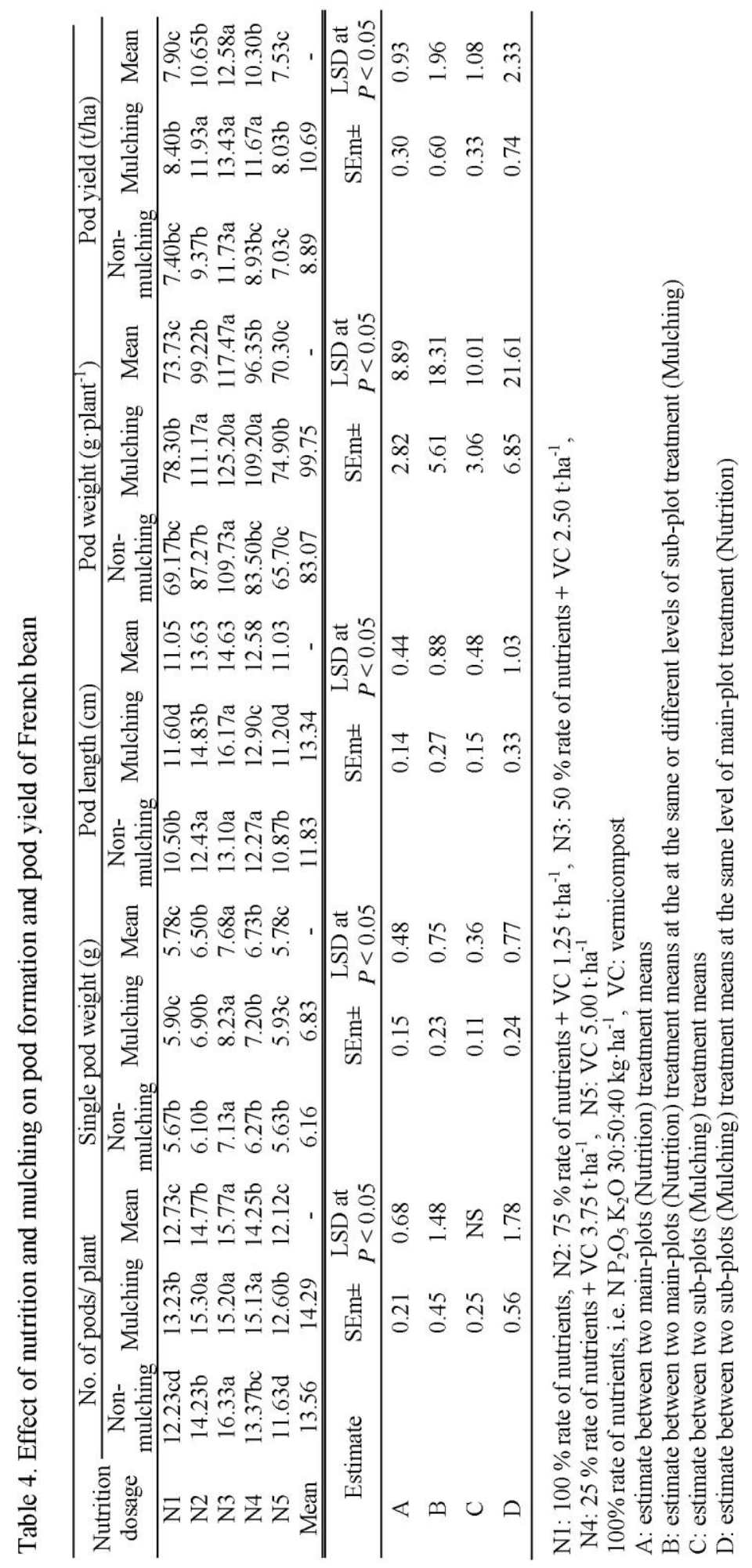




\section{Effect of vermicompost, fertilizer and mulching on pod formation and pod yield of French bean}

The pod related parameters such as pod number, single pod weight, pod length, pod weight/plant and pod yield life articulated significant differences by various sources of nutrients and mulch, apart from number of pods by mulch (Table 4). Maximum pod number, pod length, pod weight/plant and pod yield were observed with N3 treatment followed by N2, N4, N1 and N5 treatment. However, single pod weight was highest for $\mathrm{N} 3$ treatment followed by N4 and N2 and lowest for $\mathrm{N} 1$ and N5 treatment. Mulching of French bean with dried grasses and crop residues led to higher single pod weight, pod length, pod weight/plant and pod yield by 10.9, 12.8, 20.1 and $20.2 \%$, respectively. The interactive effects of nutrients and mulch on green pod length were significantly

\section{CONCLUSION}

The increased amount of humus in soil through application of vermincompost and decomposition of organic mulches by earthworms would certainly help favourable change in physical, chemical and biological properties of soil, and in enhancing the water-holding capacity. In conclusion, the present study shows that application of $\mathrm{N} \mathrm{P}_{2} \mathrm{O}_{5} \mathrm{~K}_{2} \mathrm{O}$ fertilizer 8-15:1325:10-20 kg $\cdot$ ha $^{-1}$, vermicompost 2.50 $3.75 \mathrm{t} \cdot \mathrm{ha}^{-1}, 4 \mathrm{~cm}$ thick mulch of dried crop residues and 50\% irrigation is the most suitable and sustainable strategy to improve plant growth, pod formation and pod yield of French bean, and soil health of mild-tropical climate during dry season.

\section{Acknowledgement}

We would like express our special thanks to the Director, ICAR Research Complex for NEH Region, Umroi Road, Barapani793103, Meghalaya, India for his financial support for the present research.

\section{REFERENCES}

Adetunji I.A. 1990. Effect of mulches and irrigation on growth and yield of lettuce in semi-arid region. Biotronics 19: 93-98.

Aggelides S.M., Londra P.A. 1999. Effect of compost produced from town waste and sewage sludge on the physical properties of a loamy and a clay soil. Bioresource Technology 71: 253-259.

Alam M.N., Jahan M.S., Ali M.K., Islam M.S., Khandaker S.M.A.T. 2007. Effect of vermicompost and NPKS fertilizers on growth, yield and yield components of red amaranth. Australian Journal of Basic and Applied Science 1 (4): 706-716.

Albiach R., Canet R., Pomares F., Ingelmo F. 2000. Microbial biomass content and enzymatic activities after application of organic amendments to a horticultural soil. Bioresource Technology 75: 43-48.

Anikwe M.A.N., Mbah C.N., Ezeaku P.I., Onyia V.N. 2007. Tillage and plastic mulch effects on soil properties, and growth and yield of cocoyam (Colocasia esculenta) on an ultisol in south-eastern Nigeria. Soil and Tillage Research 93: 264-272.

Ansari A.A. 2008. Effect of vermicompost and vermiwash on the productivity of spinach Spinacia oleracea), onion (Allium cepa) and potato (Solanum tuberosum). World Journal of Agricultural Sciences 4 (5): 554557.

Arancon N.Q, Edwards C.A., Bierman P. 2006. Influences of vermicomposts on field strawberries: Part 2. Effects on soil microbial and chemical 
properties. Bioresource Technology 97: 831-840.

Arguello J.A., Ledesma A., Nunez S.B., Rodriguez C.H., Goldfarb M.D.C.D. 2006. Vermicompost effects on bulbing dynamics, non-structural carbohydrate content, yield and quality of 'Rosado Paraguayo' garlic bulb. HortScience 41 (3): 589592.

Arora V.K., Singh C.B., Sidhu A.S., Thind S.S. 2011. Irrigation, tillage and mulching effects on soybean yield and water productivity in relation to soil texture. Agricultural Water Management 98: 563-568.

Atiyeh R.M., Edwards C.A., Sulber S., Metzger J.D. 2001. Pig manure's vermicompost as a component of a horticultural bedding plant medium: Effects on physiochemical properties and plant growth. Bioresource Technology 78: 11-20.

Azarmi R., Giglou M.T. Taleshmikail R.D. 2008. Influence of vermicompost on soil chemical and physical properties in tomato field. African Journal of Biotechnology 7 (14): 2397-2401.

Bhatt R., Khera K.L. 2006. Effect of tillage and mode of straw mulch application on soil erosion in the submountainous tract of Punjab, India. Soil and Tillage Research 88: $107-$ 115.

Chanda G.C., Bhunia G., Chakraborty S.K. 2011. The effect of vermicompost and other fertilizers on cultivation of tomato plants. Journal of Horticulture and Forestry 3 (2): 42-45.

Ekinci M., Dursun A. 2009. Effects of different mulch materials on plant growth, some quality parameters and yield in melon (Cucumis melo L.) cultivars in high altitude environmental condition. Pakistan Journal of Botany 41 (4): 1891-1901.

Glab T., Kulig B. 2008. Effect of mulch and tillage system on soil porosity under wheat (Triticum aestivum).
Soil and Tillage Research 99: 169 178.

Gupta A.K., Pankaj P.K., Upadhyaya V. 2008. Effect of vermicompost, farm yard manure, biofertilizer and chemical fertilizers (NPK) on growth, yield and quality of Abelmoschus esculentus. Pollution Research 27 (1): 65-68.

Liasu M.O., Ogundare A.O., Ologunde M.O. 2008. Effect of soil supplementation with fortified tithonia mulch and directly applied inorganic fertilizer on growth and development of potted okra plants. American Eurasian Journal of Sustainable Agriculture 2 (3): 264-270.

Marinari S., Masciandaro G., Ceccanti B., Grero S. 2000. Influence of organic and mineral fertilizers on soil biological and physical properties. Bioresource Technology 72: 9-17.

Mascolo A., Bovalo F., Gionfriddo F., Nardi S. 1999. Earthworm humic matter produces auxin like effects on Daucus carota cell growth and nitrogen metabolism. Soil Biology and Biochemistry 31: 1303-1313.

Peyvast G., Olfati J.A., Madeni S., Forghani A. 2008. Effect of vermicompost on the growth and yield of spinach (Spinacia oleracea L.). Journal of Food Agriculture and Environment 6 (1): 110-113.

Prabha K.P, Loretta Y.L., Usha R.K. 2007. An experimental study of vermin-biowaste composting for agricultural soil improvement. Bioresource Technology 99: 1672-1681.

Premsekhar M., Rajashree V. 2009. Influence of organic manures on growth, yield and quality of okra. American Eurasian Journal of Sustainable Agriculture 3 (1): 6-8.

Rashidi M., Abbassi S., Gholami M. 2009. Interactive effects of plastic mulch and tillage method on yield and yield components of tomato (Lycopersicon esculentum). American Eurasian Journal of Agriculture 
and Environmental Science 5: 420427.

Sailajakumari M.S., Ushakumari K. 2002. Effect of vermicompost enriched with rock phosphate on the yield and uptake of nutrients in cowpea (Vigna unguiculata L. Walp.). Journal of Tropical Agriculture 40: 2730.

Sarkar S., Paramanick M., Goswami S.B. 2007. Soil temperature, water use and yield of yellow sarson (Brassica napus L. var. glauca) in relation to tillage intensity and mulch management under rainfed lowland ecosystem in eastern India. Soil and Tillage Research 93: 94-101.

Sarkar S., Singh S.R. 2007. Interactive effects of tillage depth and mulch on soil temperature, productivity and water use pattern of rainfed barley (Hordeum vulgare L.). Soil and Tillage Research 92: 79-86.

Singh B.K, Pathak K.A., Boopathi T., Deka B.C. 2010. Vermicompost and
NPK fertilizer effect on morphophysiological, yield and quality of tomato (Solanum lycopersicum). Veget. Crops Res. Bull. 73: 77-86. [DOI: 10.2478/v10032-010-0020-0]

Suthar S. 2009. Impact of vermicompost and composted farm yard manure on growth and yield of garlic (Allium stivum L.) field crop. International Journal of Plant Production 3 (1): 27-38.

Suthar S., Choyal R., Singh S., Sudesh. 2005. Stimulatory effect of earthworm body fluid (vermiwash) on seed germination and seedling growth of two legumes. Journal of Phytological Research 18 (2): 219 222.

Vanlalhluana P.C., Sahoo U.K. 2011. Growth and yield of maize under different agroforestry systems exposed to varying cultural treatments in Mizoram, India. Sci Vis 11 (1): 11-15.

\section{WPŁYW WERMIKOMPOSTU, NAWOŻENIA MINERALNEGO \\ I ŚCIÓŁKOWANIA NA WZROST ROŚLIN, TWORZENIE BRODAWEK KORZENIOWCH I PLON STRĄKÓW FASOLI ZWYCZAJNEJ (PHASEOLUS VULGARIS L.)}

\section{Streszczenie}

Integracja wermikompostu i ściółek organicznych jako elementów systemu produkcji warzyw przyczynia się do utrzymania żyzności gleby i wydajności upraw. Przeprowadzono doświadczenie polowe, którego celem było zbadanie wpływu wermikompostu, nawozu NPK oraz ściółki organicznej na wzrost roślin, tworzenie brodawek korzeniowych i plon strąków fasoli zwyczajnej (Phaseolus vulgaris L.), a w końcowym rezultacie zoptymalizowanie zapotrzebowania na wodę i składniki mineralne w łagodnym klimacie tropikalnym w okresie pory suchej. Cechy wzrostu pędów, a mianowicie, długość pędu, liczba rozgałęzień głównych, świeża i sucha masa pędów, wzrosły o 28 -

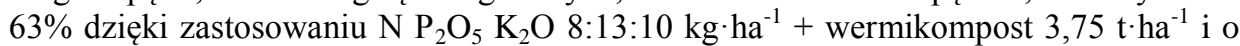
$5-50 \%$ po zastosowaniu ściółki organicznej. Zastosowanie wermikompostu zmniejszyło świeżą i suchą masę brodawek korzeniowych odpowiednio o 44,9 i 44,5\%. Podobnie w przypadku ściółkowania organicznego, liczba brodawek korzeniowych, oraz świeża i sucha masa brodawek zostały zmniejszone o 8,6; 11,1 i 14,1\%. Słabe tworzenie się brodawek korzeniowych może być spowodowane zmniejszonym natlenieniem gleby pod wermikompostem i ściółką organiczną, które ostatecznie utrudniają aktywność nitrogenazy i biologiczne wiązanie azotu. Ściółkowanie roślin fasoli zwyczajnej suszonymi trawami i resztkami pożniwnymi przyczyniło się również do większej masy poje- 
dynczego strąka, długości strąka, masy strąka na roślinę oraz plonu strąków odpowiednio o 10,$9 ; 12,8 ; 20,1$ i 20,2\%. Niniejsze badania pokazują, że zastosowanie nawozu N $\mathrm{P}_{2} \mathrm{O}_{5} \mathrm{~K}_{2} \mathrm{O}$ w dawce 8-15:13-25:10-20 $\mathrm{kg} \cdot \mathrm{ha}^{-1}$, wermikompostu w dawce 2,50-3,75 $\mathrm{t} \cdot \mathrm{ha}$ ${ }^{1}$, i ściółki z suchych resztek pożniwnych o grubości $4 \mathrm{~cm}$, oraz $50 \%$ nawadniania jest najbardziej odpowiednią i zrównoważoną strategią w celu poprawy wzrostu roślin, wytwarzania strąków i plonu strąków fasoli zwyczajnej, oraz zdrowotności gleby w łagodnym klimacie tropikalnym w okresie pory suchej. 